\title{
CLR and ARL Announce New Academic Library Program
}

The Council on Lihrary Resources, Inc. (CLR) has made a grant of $\$ 326,500$ to the Association of Research Libraries (ARL), Office of University Library Management Studies, in support of the new Academic Library Program (ALP) that will assist a large number of academic libraries in conducting self-study programs to improve their effectiveness. The five-year grant has been enhanced by a grant of $\$ 250,000$ from the Andrew W. Mellon Foundation and the commitment of a like amount from the Association of Research Libraries for a total budget of $\$ 826,500$.

The Academic Library Program will allow a large number of libraries in two- and four-year colleges and in universities to take advantage of tested self-study methods to assess and improve library services and refine managerial and operational practices. At the heart of the undertaking is an Office of Management Studies (OMS) plan to train about 100 outstanding librarians to serve as consultants in specific areas (e.g., collection development, management processes, library services), to provide the consultants with specialized guides and manuals, and to give backup assistance to the consultants when appropriate.

The initiative for taking advantage of the skills and services of OMS and the consultants will rest with the colleges and universities themselves. They will need to commit a reasonable amount of staff time and a small amount of money in order to improve library services and to bring program objectives into balance with financial resources and operating capabilities.

The Academic Library Program builds upon tested programs of the Office of Management Studies, such as the Management Review and Analysis Program (MRAP) and the Academic Library Development Program (ALDP), which are supported by the Council on Library Resources, and the Collection Analysis Project (CAP), supported by the Mellon Foundation.

MRAP presents a framework within which large academic and research library staffs analyze their management systems to identify strengths and weaknesses and to outline areas for action and change. CAP is designed to help academic libraries assess collection development practices. A manual provides a systematic method for examining such areas as collecting goals, allocation procedures, organization, staffing patterns, decision-making processes, and preservation. ALDP provides a strategy for small and medium-sized academic libraries to use in examining their operations, services, and management practices. In addition to these, the OMS staff will develop methods and materials focused on specialized areas

By consolidating related programs and capitalizing on past efforts, ALP will provide the flexibility required to help individual libraries address their own specific problems. It is also expected that ALP will encourage academic libraries of all kinds to draw more closely together, an important goal when libraries are seeking more effective means to meet the bibliographic, resource, and service needs of all faculty members and students.

Development and operation of the Academic Library Program will be guided by advice from librarians and others concerned with the quality of library service. The Board of Directors of the Association of College and Research Libraries (ACRL), a division of the American Library Association, strongly endorsed the new program at its June 1978 meeting and voted that ACRL actively participate with ARL and CLR in the design and development of the program. Further information about ALP and application procedures will be available from the ARL Office of Management Studies early in the fall of 1978.

The Office of University Library Management Studies, established by ARL, assists libraries in effectively serving the academic and research community through sound management of the resources available to them. The emphasis of the office is on developing practical methods for improving library performance. In addition to the Academic Library Program, the office operates a library staff training program and an information clearinghouse dedicated to the sharing of management information and expertise among academic librarians.

The Council on Library Resources is a private operating foundation. Through grants to and contracts with other organizations and individuals, CLR seeks to assist in finding solutions to the problems of libraries, particularly academic and research libraries. The council was established in 1956 by the Ford Foundation and continues to receive support from it as well as other foundations. This grant was made possible primarily through funds received by the council from the Carnegie Corporation of New York for programs to improve research library management. 